\title{
Pemanfaatan Algoritma Porter Stemmer Untuk Bahasa Indonesia Dalam Proses Klasifikasi Jenis Buku
}

\author{
Bonifacius Vicky Indriyono ${ }^{1}$, Ema Utami ${ }^{2}$, Andi Sunyoto ${ }^{3}$ \\ Program Pascasarjana Magister Teknik Informatika STMIK AMIKOM Yogyakarta \\ Jl. Ring Road Utara Condong Catur, Depok, Sleman, Yogyakarta \\ E-mail: ${ }^{1}$ bonifaciusvicky@gmail.com, ${ }^{2}$ emma@nrar.net, ${ }^{3}$ andi@amikom.ac.id \\ Masuk: 3 Mei 2015; Direvisi: 19 Mei 2015; Diterima: 22 Mei 2015
}

\begin{abstract}
Stemming is the process of mapping and decomposition of various forms (variants) of a word to essentially find the root word. This process is also referred to as the conflation. Stemming process has been widely used in the activities of the information retrieval (search information) to improve the quality of the information obtained. Stemming works by employing words taken froma dictionary and the usage of the basic rules of affixes. Porter stemmer for Indonesian or commonly referred as Tala stemmer uses the rules of basic analysis to find the root of a word. Tala Stemmer does not use a dictionary in the process. Instead, it uses a rule-based algorithm. In this study, the principal issue raised is how to make the process of classification/determination of the book/library materials in a library with a fast and effective manner in order to minimize error in determining the type of books. The solution is to utilize the method used by the porter stemmer for stemming Indonesian.
\end{abstract}

Keywords: Stemming, Information Retrieval, Porter Stemmer, Classification

\begin{abstract}
Abstrak. Stemming adalah proses pemetaan dan penguraian berbagai bentuk (variants) dari suatu kata menjadi bentuk kata dasarnya. Proses ini juga disebut sebagai conflation. Proses stemming secara luas sudah digunakan di dalam kegiatan Information retrieval (pencarian informasi) untuk meningkatkan kualitas informasi yang didapatkan. Cara kerja stemming dapat dilakukan dengan menggunakan kamus kata dasar maupun menggunakan aturan-aturan imbuhan. Porter stemmer untuk Bahasa Indonesia atau yang biasa disebut dengan stemmer Tala menggunakan rule base analisis untuk mencari root sebuah kata. Stemmer Tala tidak menggunakan kamus dalam proses, melainkan menggunakan algoritma berbasis aturan. Dalam penelitian ini, pokok permasalahan yang diangkat adalah bagaimana melakukan proses klasifikasi/penentuan jenis buku/bahan pustaka dalam sebuah perpustakaan dengan cara yang cepat dan efektif sehingga dapat meminimalisir kesalahan penentuan jenis buku. Solusi yang dipergunakan adalah dengan memanfaatkan metode stemming dengan porter stemmer untuk bahasa Indonesia.
\end{abstract}

Kata Kunci: Stemming, Information Retrieval, Porter Stemmer, Klasifikasi

\section{Pendahuluan}

Dewasa ini, buku merupakan salah satu sarana pemberi informasi bagi masyarakat luas. Ibarat kata, buku adalah jendela informasi dunia, maka segala kebutuhan akan informasi apapun tersaji dalam pustaka buku. Untuk mempermudah pencarian informasi yang sesuai dengan yang diinginkan oleh pencari informasi dan sesuai dengan waktunya, maka pengklasifikasifikasian dokumen akan membantu bagaimana mendapatkan informasi, sehingga mempermudah pengolahan dan penggunaannya sesuai kebutuhan dan tujuan yang ingin dicapai. Klasifikasi adalah proses menemukan model atau fungsi yang menjelaskan atau membedakan konsep/kelas data, dengan tujuan dapat memperkirakan kelas dari suatu objek dan merupakan proses awal pengelompokkan data. Proses klasifikasi dokumen merupakan proses yang sangat penting dalam bidang sistem informasi, khususnya dalam proses penambangan data (data mining) untuk memperoleh pengetahuan bisnis (Mulyanto, 2009). Menurut (Walpole dan Myers, 1995), klasifikasi adalah salah satu tugas yang penting dalam data mining. Permasalahan yang muncul 
sekarang adalah bagaimana melakukan proses klasifikasi buku dengan cepat dan efektif agar buku dapat benar-benar berada pada jenis yang sebenarnya.

Permasalahan yang diuraikan di atas dapat diatasi dengan menggunakan metode dalam text preprocessing yang dilakukan sebelum tahap klasifikasi. Metode ini dikenal dengan istilah stemming. Stemming adalah proses pemetaan dan penguraian berbagai bentuk (variants) dari suatu kata menjadi bentuk kata dasarnya. Proses ini juga disebut sebagai conflation (Tala, 2003). Proses stemming secara luas sudah digunakan di dalam kegiatan information retrieval (pencarian informasi) untuk meningkatkan kualitas informasi yang didapatkan. Pada analisa temu kembali informasi imbuhan merupakan bagian dari informasi yang tidak bermakna, seperti halnya stop word. Sehingga imbuhan harus dihilangkan untuk mempercepat proses index. Cara kerja stemming dapat dilakukan dengan menggunakan kamus kata dasar maupun menggunakan aturan-aturan imbuhan. Dalam penelitian ini, dipergunakan metode porter stemmer atau yang dikenal dengan nama stemmer Tala. Metode ini tidak menggunakan kamus kata dasar tetapi menggunakan algoritma berbasis aturan dalam proses kerjanya.

Tujuan yang ingin dicapai dalam penelitian ini diantaranya: (1) Memahami aturan-aturan dalam Porter Stemmer untuk bahasa Indonesia. (2) Dapat menerapkan aturan Porter Stemmer untuk Bahasa Indonesia untuk proses klasifikasi jenis buku berbahasa Indonesia dalam sebuah prototype. Beberapa manfaat yang dapat diambil dari penelitian ini diantaranya: (1) Penelitian ini diharapkan dapat menambah wawasan dan pengetahuan peneliti tentang aturan-aturan dalam porter stemmer untuk Bahasa Indonesia. (2) Dapat membantu mempermudah dalam proses klasifikasi jenis buku dengan menerapkan aturan-aturan dalam porter stemmer untuk Bahasa Indonesia. (3) Dapat membantu mempercepat proses klasifikasi dengan terbentuknya kata dasar dari implementasi porter stemmer untuk Bahasa Indonesia.

\section{Tinjauan Pustaka}

\subsection{Penelitian Terdahulu}

Beberapa penelitan tentang penerapan metode Nä̈ve Bayes Classifier yang sudah pernah dilakukan peneliti sebelumnya antara lain penelitian yang dilakukan oleh: (1) Indranandita, dkk. (2008) menjelaskan penggunaan porter stemmer untuk proses transformasi teks dalam sistem klasifikasi dan pencarian jurnal menggunakan metode Nä̈ve Bayes Classifier dan Vector Space Model. (2) Agusta (2009) memaparkan pemanfaatan algoritma porter stemmer Bahasa Indonesia dalam proses klasifikasi dokumen dan membandingkannya dengan algoritma Nazief \& Adriani. (3) Baskoro, dkk. (2012) menjelaskan tentang langkahlangkah/algoritma, aturan dan pemanfaatan porter stemmer dalam Bahasa Indonesia. (4) Budhi, dkk. (2012) menjelaskan cara pembuatan kata kunci secara otomatis dengan menggunakan GenEx dan memanfaatkan porter stemmer for bahasa Indonesia untuk penyesuaian kata kunci. Dari hasil penelitian ini, disimpulkan bahwa porter stemmer for bahasa Indonesia dapat digunakan untuk membantu dalam proses penyesuaian kata kunci. (5) Utomo (2013) memaparkan pemanfaatan stemmer Tala untuk temu kembali informasi yang diterapkan dalam sebuah aplikasi berbasis web. Hasil dari penelitian ini, bahwa stemmer Tala yang merupakan algoritma berbasis aturan memiliki performa yang stabil dengan jumlah dokumen yang berkembang. (6) Pradnyana dan Sanjaya (2012) menguraikan penggunaan algoritma porter stemmer Bahasa Indonesia pada proses penemuan kalimat-kalimat penting dari tiap dokumen dalam sistem Automated Document Integration. (7) Karaa (2013) memaparkan tentang pemanfaatan algoritma porter stemmer untuk proses information retrieval (temu kembali informasi).

\subsection{Pengertian Klasifikasi}

Mulyanto (2009) mengatakan proses klasifikasi adalah proses menemukan model atau fungsi yang menjelaskan atau membedakan konsep/kelas data, dengan tujuan dapat memperkirakan kelas dari suatu objek dan merupakan proses awal pengelompokkan data. Proses klasifikasi dokumen merupakan proses yang sangat penting dalam bidang sistem informasi, khususnya dalam proses penambangan data (data mining) untuk memperoleh 
pengetahuan bisnis (business knowledge). Klasifikasi adalah salah satu tugas yang penting dalam data mining.

Dalam klasifikasi, sebuah pengklasifikasi dibuat dari sekumpulan data latih dengan kelas yang telah di tentukan sebelumnya (Walpole dan Myers, 1995), sedangkan menurut Han dan Kamber (2001), proses klasifikasi dibagi menjadi dua tahap, yaitu tahapan learning dan testing. Pada tahap learning/pembelajaran, sebagian data yang telah diketahui kelasnya (data latih) digunakan untuk membuat model klasifikasi. Tahap testing/pengujian menguji data uji dengan model klasifikasi untuk mengetahui akurasi model klasifikasi tersebut. Menurut Tenenboim, dkk (2008), klasifikasi dokumen adalah bidang penelitian dalam perolehan informasi yang mengembangkan metode untuk menentukan atau mengkategorikan suatu dokumen ke dalam satu atau lebih kelompok yang telah dikenal sebelumnya secara otomatis berdasarkan isi dokumen.

\subsection{Manfaat Klasifikasi}

Menurut Eryono (1999), manfaat yang dapat diambil dari proses klasifikasi dokumen/bahan pustaka adalah sebagai berikut: (1) Buku/bahan pustaka yang sama atau mirip isinya akan terletak pada tempat yang berdekatan. (2) Memudahkan dalam mengadakan perimbangan koleksi yg dimiliki. (3) Memudahkan penelusuran terhadap bahan pustaka menurut subyek. (4) Memudahkan dalam membuatkan bibliografi menurut pokok masalah. Manfaat klasifikasi yang lainnya menurut Tenenboim (2008) adalah untuk mengelompokkan dokumen yang tidak terstruktur ke dalam kelompok-kelompok yang menggambarkan isi dari dokumen.

\subsection{Pengertian Stemming}

Stemming adalah proses pemetaan dan penguraian berbagai bentuk (variants) dari suatu kata menjadi bentuk kata dasarnya (Porter, 1980). Proses ini juga disebut sebagai conflation. Proses stemming secara luas sudah digunakan di dalam information retrieval (pencarian informasi) untuk meningkatkan kualitas informasi yang didapatkan (Frakes dan Baeza, 1992).

Stemming adalah suatu teknik pencarian bentuk dasar dari suatu term. Yang dimaksud dengan term itu sendiri adalah tiap kata yang berada pada suatu dokumen teks. Stemming dilakukan pada saat pembuatan indeks dari suatu dokumen. Pembuatan indeks dilakukan karena suatu dokumen tidak dapat dikenali langsung oleh suatu sistem temu kembali informasi atau information retrieval (IR) sistem. Oleh karena itu, dokumen tersebut terlebih dahulu perlu dipetakan ke dalam suatu representasi dengan menggunakan teks yang berada di dalamnya. Menurut Tala (2003), tujuan dari proses stemming adalah menghilangkan imbuhanimbuhan baik itu berupa prefiks, sufiks, maupun konfiks yang ada pada setiap kata.

\subsection{Porter Stemmer Untuk Bahasa Indonesia}

Porter Stemmer untuk Bahasa Indonesia atau yang dikenal dengan nama stemmer Tala, dikembangkan oleh Tala (2003). Implementasi Porter Stemmer untuk Bahasa Indonesia berdasarkan English Porter Stemmer yang dikembangkan oleh Frakes dan Baeza (1992). Karena Bahasa Inggris datang dari kelas yang berbeda, beberapa modifikasi telah dilakukan untuk membuat Algoritma Porter dapat digunakan sesuai dengan Bahasa Indonesia (Tala, 2003). Desain dari Porter Stemmer untuk Bahasa Indonesia dapat dilihat pada Gambar 1.

Dari Gambar 1 dapat dijelaskan algoritma/langkah-langkah dalam Porter Stemmer untuk Bahasa Indonesia sebagai berikut: (1) Menghapus partikel seperti: -kah, -lah, -tah. (2) Mengapus kata ganti (Possesive Pronoun), seperti -ku, -mu, -nya. (3) Menghapus awalan pertama. Jika tidak ditemukan, maka lanjut ke langkah remove 2 nd order prefix, dan jika ada maka lanjut ke langkah remove suffix. (4) (a) Menghapus awalan kedua, dan dilanjutkan pada langkah ke remove suffix. (b) Menghapus akhiran, jika tidak ditemukan maka kata tersebut diasumsikan sebagai kata dasar (root word). Jika ditemukan maka lanjut ke langkah remove 2nd order prefix. (5) (a) Menghapus akhiran dan kata akhir diasumsikan sebagai kata dasar (root word). (b) Menghapus awalan kedua dan kata akhir diasumsikan sebagai kata dasar (root word). 


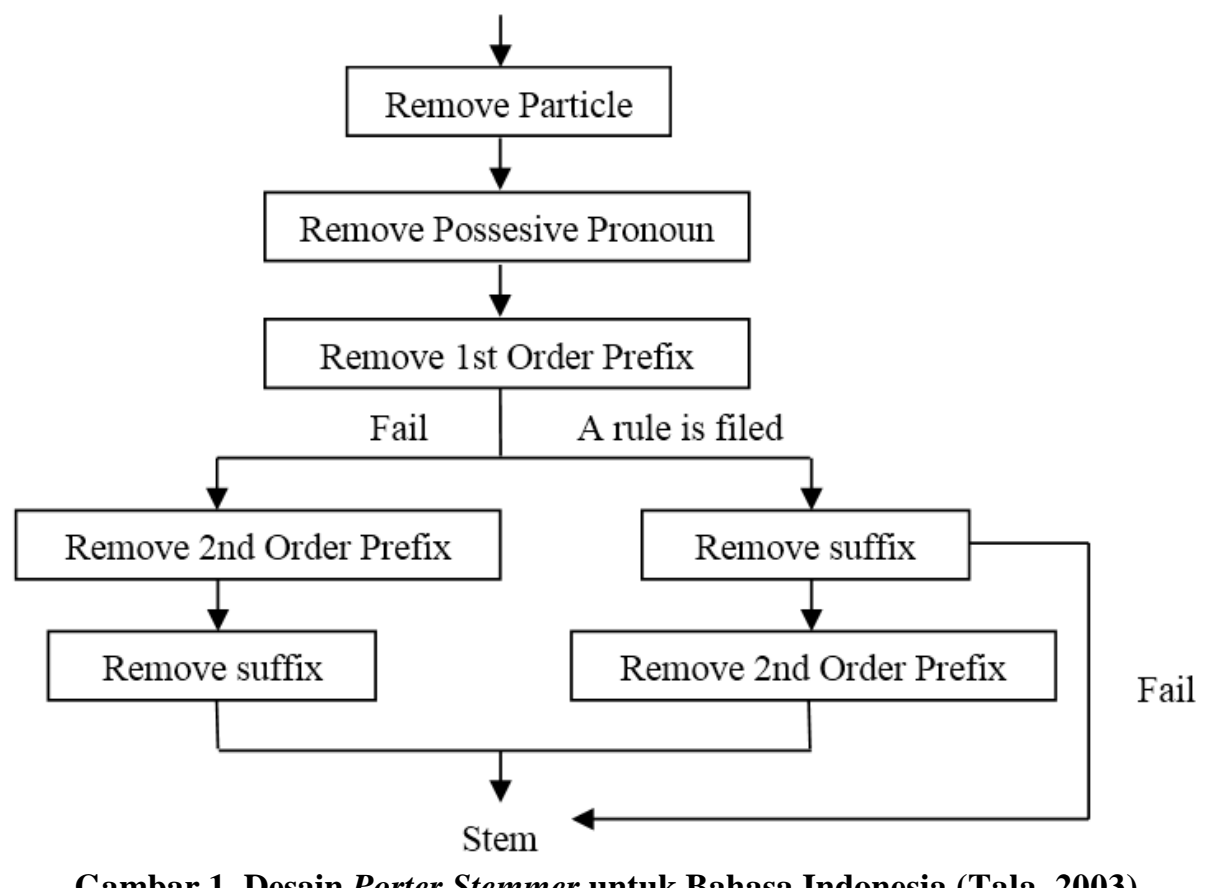

Gambar 1. Desain Porter Stemmer untuk Bahasa Indonesia (Tala, 2003)

\subsection{Aturan Porter Stemmer Untuk Bahasa Indonesia}

Terdapat lima aturan pada Algoritma Porter Stemmer untuk Bahasa Indonesia (Tala, 2003). Aturan-aturan tersebut dapat dilihat pada Tabel 1, Tabel 2, Tabel 3, Tabel 4, dan Tabel 5.

Tabel 1. Kelompok Rule Pertama: Inflectional Particles

\begin{tabular}{llll}
\hline \multicolumn{1}{c}{ Suffix } & Replacement & Additional Condition & \multicolumn{1}{c}{ Examples } \\
\hline kah & NULL & NULL & Bukukah $\rightarrow$ buku \\
\hline lah & NULL & NULL & Adalah $\rightarrow$ ada \\
\hline pun & NULL & NULL & Bukupun $\rightarrow$ buku \\
\hline
\end{tabular}

Tabel 2. Kelompok Rule Kedua: Inflectional Possesive Pronouns

\begin{tabular}{llll}
\hline \multicolumn{1}{c}{ Suffix } & Replacement & Additional Condition & \multicolumn{1}{c}{ Examples } \\
\hline $\mathrm{ku}$ & NULL & NULL & Bukuku $\rightarrow$ buku \\
\hline $\mathrm{mu}$ & NULL & NULL & Bukumu $\rightarrow$ buku \\
\hline $\mathrm{nya}$ & NULL & NULL & Bukunya $\rightarrow$ buku \\
\hline
\end{tabular}

Tabel 3. Kelompok Rule Ketiga: First Order of Derivational Prefixes

\begin{tabular}{cccc}
\hline Suffix & Replacement & Additional Condition & Examples \\
\hline meng & NULL & NULL & Mengukur $\rightarrow$ ukur \\
\hline meny & S & V... & Menyapu $\rightarrow$ sapu \\
\hline men & NULL & NULL & $\begin{array}{l}\text { Menduga } \rightarrow \text { duga; } \\
\text { Menuduh } \rightarrow \text { uduh }\end{array}$ \\
\hline mem & P & V... & Memilah $\rightarrow$ pilah \\
\hline mem & NULL & NULL & Membaca $\rightarrow$ baca \\
\hline me & NULL & NULL & Merusak $\rightarrow$ rusak \\
\hline peng & NULL & NULL & Pengukur $\rightarrow$ ukur \\
\hline peny & S & V... & Penyapu $\rightarrow$ sapu \\
\hline pen & NULL & NULL & Penduga $\rightarrow$ duga; \\
\hline pem & P & V... & Penuduh $\rightarrow$ uduh \\
\hline pem & NULL & NULL & Pemilah $\rightarrow$ pilah \\
\hline di & NULL & NULL & Pembaca $\rightarrow$ baca \\
\hline ter & NULL & NULL & Diukur $\rightarrow$ ukur \\
\hline ke & NULL & NULL & Tersapu $\rightarrow$ sapu \\
\hline & & Kekasih $\rightarrow$ kasih \\
\hline
\end{tabular}


Tabel 4. Kelompok Rule Keempat: Second Order of Derivational Prefixes

\begin{tabular}{llcl}
\hline \multicolumn{1}{c}{ Suffix } & Replacement & Additional Condition & \multicolumn{1}{c}{ Examples } \\
\hline ber & NULL & NULL & Berlari $\rightarrow$ lari \\
\hline bel & NULL & ajar & Belajar $\rightarrow$ ajar \\
\hline be & NULL & K* er... & Bekerja $\rightarrow$ kerja \\
\hline per & NULL & NULL & Perjelas $\rightarrow$ jelas \\
\hline pel & NULL & ajar & Pelajar $\rightarrow$ ajar \\
\hline pe & NULL & NULL & Pekerja $\rightarrow$ kerja \\
\hline
\end{tabular}

Tabel 5. Kelompok Rule Kelima: Derivational Suffixes

\begin{tabular}{llll}
\hline \multicolumn{1}{c}{ Suffix } & Replacement & \multicolumn{1}{c}{ Additional Condition } & \multicolumn{1}{c}{ Examples } \\
\hline kan & NULL & Prefix $\notin\{\mathrm{ke}$, peng $\}$ & Tarikkan $\rightarrow$ tarik; (meng)ambilkan $\rightarrow$ ambil \\
\hline an & NULL & Prefix $\notin\{$ di, meng, ter $\}$ & Makanan $\rightarrow$ makan;(per $)$ janjian $\rightarrow$ janji \\
\hline i & NULL & V|K...c $1 \mathrm{c} 1, \mathrm{c} 1 \neq \mathrm{i}, \mathrm{c} 2 \neq \mathrm{i}$ and Prefix $\notin\{$ ber, ke, peng $\}$ & $\begin{array}{l}\text { Tandai } \rightarrow \text { tanda;(men)dapati } \rightarrow \text { dapat; } \\
\text { Pantai } \rightarrow \text { panta }\end{array}$ \\
\hline
\end{tabular}

\section{Pembahasan dan Implementasi}

\subsection{Pembahasan}

Sebelum dilakukan proses klasifikasi, data buku yang akan diproses untuk menentukan jenis bukunya, terlebih dahulu melalui tahap text preprocessing. Pada tahap text preprocessing dilakukan beberapa proses untuk menyiapkan judul dan sinopsis buku yang akan menjadi dokumen teks yang siap diolah pada tahap selanjutnya. Menurut Garcia (2005) pada tahap text preprocessing ini pada umumnya terdapat beberapa proses, antara lain tokenizing, stopword removal, filtering, stemming dan term weighting. Adapun tahap text preprocessing yang dilakukan dalam penelitian ini diperlihatkan pada Gambar 2.

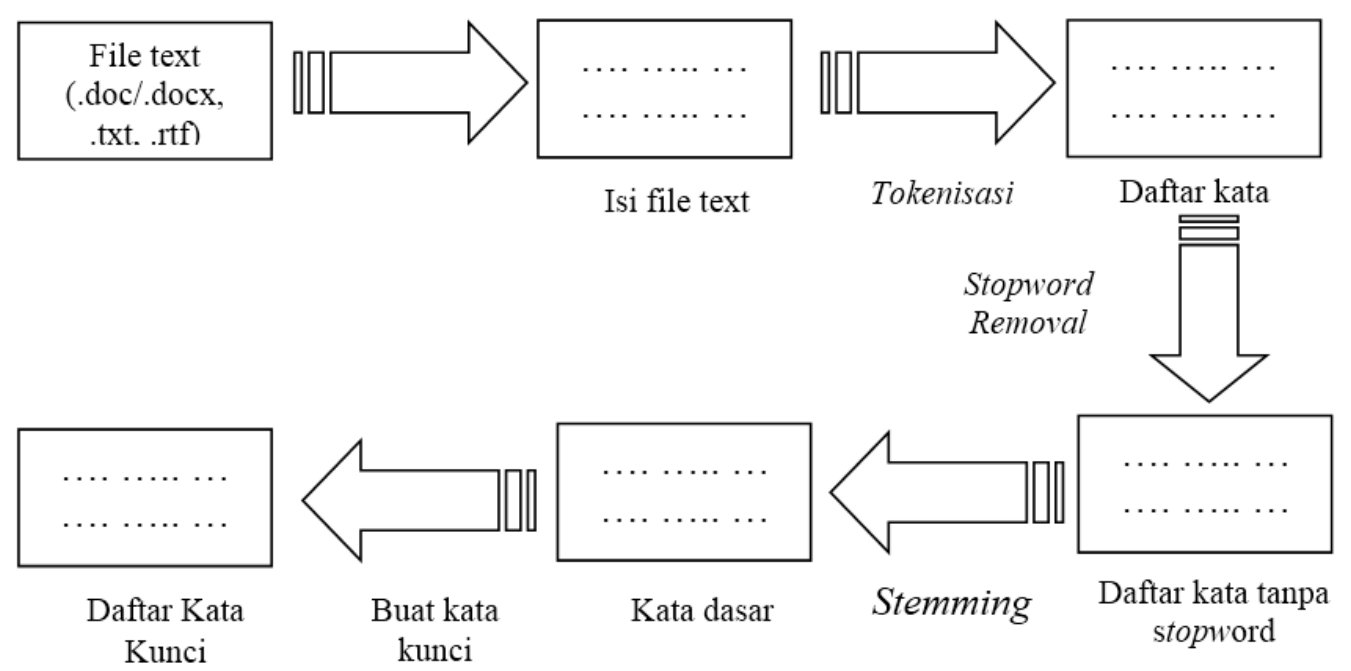

Gambar 2. Bagan Tahap Text Preprocessing dalam Penelitian

\subsubsection{Tokenizing}

Selama proses tokenizing berlangsung semua string input akan diuraikan sesuai dengan tiap kata yang menyusunnya. Setiap huruf input akan diubah menjadi huruf kecil. Semua tanda baca dan tanda hubung akan dihapuskan, termasuk semua karakter selain huruf alphabet (Garcia, 2005). Pada penelitian ini, tahap tokenizing akan melakukan pemisahan terhadap kata demi kata dari teks judul dan sinopsis buku yang dimasukkan. Tanda baca juga dihilangkan dalam proses ini, sehingga dokumen akan menghasilkan beberapa token yang akan diproses lebih lanjut. Contoh proses ini seperti diperlihatkan pada Gambar 3.

\subsubsection{Stopword Removal}

Pada bagian ini, sistem baru akan melakukan proses membuang kata-kata yang tidak bermakna dari daftar token yang dihasilkan pada proses tokenizing. Contoh proses stopword removal diperlihatkan pada Gambar 4. 
ACTIVE SERVER PAGES DATABASE

Tidak ada yang mengira bahwa dunia database mampu mengubah cara hidup banyak orang dimuka bumi ini. Dulu, datbase hanya diposisikan sebagai alat administratif belaka, seperti mendata nama murid, nama pasien, logistik dan lain sebagainya.

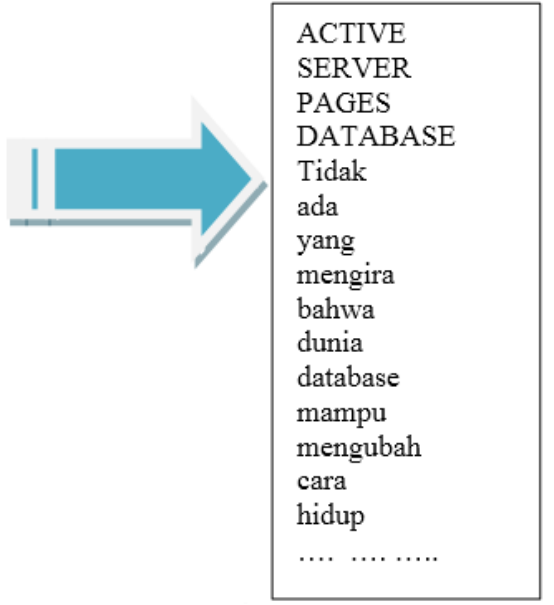

Gambar 3. Contoh Tahap Tokenizing

\begin{tabular}{|c|c|c|c|c|}
\hline $\begin{array}{l}\text { ACTIVE } \\
\text { SERVER } \\
\text { PAGES } \\
\text { DATABASE } \\
\text { Tidak } \\
\text { ada } \\
\text { yang } \\
\text { mengira } \\
\text { bahwa } \\
\text { dunia } \\
\text { database } \\
\text { mampu } \\
\text { mengubah } \\
\text { cara } \\
\text { hidup } \\
\ldots . . . . . . . \\
\ldots . . . . . . . \\
\end{array}$ & Stopword & $\begin{array}{l}\text { Tidak } \\
\text { ada } \\
\text { yang } \\
\text { mengira } \\
\text { bahwa } \\
\text { mampu } \\
\text { cara } \\
\text { banyak } \\
\text { orang } \\
\text { ini } \\
\text { Dulu } \\
\text { hanya } \\
\text { sebagai } \\
\text { seperti } \\
\text {......... } \\
\text {......... }\end{array}$ & $\begin{array}{l}\text { Stopword } \\
\text { removal }\end{array}$ & $\begin{array}{l}\text { ACTIVE } \\
\text { SERVER } \\
\text { PAGES } \\
\text { DATABASE } \\
\text { dunia } \\
\text { database } \\
\text { mengubah } \\
\text { hidup } \\
\text { dimuka } \\
\text { bumi } \\
\text { datbase } \\
\text { diposisikan } \\
\text { alat } \\
\text { administratif }\end{array}$ \\
\hline
\end{tabular}

Gambar 4. Contoh Tahap Stopword Removal

\subsubsection{Stemming}

Pada bagian ini dilakukan proses menghilangkan imbuhan, awalan, akhiran dan kata depan pada term hasil dari proses stopword removal, sehingga term dapat menjadi bentuk kata dasarnya. Metode stemming yang digunakan adalah Porter Stemmer untuk Bahasa Indonesia atau yang lebih dikenal sebagai stemming Tala. Dengan ditemukannya kata dasar dari term, maka dapat ditemukan pula intensitas kemunculan term dalam tiap dokumen melalui proses indexing. Contoh stemming dapat dilihat pada Gambar 5.

\subsubsection{Indexing}

Setelah tahap stemming dilakukan, maka data term yang dihasilkan dari input judul dan sinosis dari beberapa buku, diubah ke dalam term frequency (TF). TF adalah frekuensi kemunculan suatu term dalam tiap dokumen. Data TF tersebut kemudian disimpan untuk digunakan dalam proses klasifikasi. Pada proses klasifikasi ini, kata-kata yang telah dihasilkan dari proses stemming dan indexing akan digunakan untuk mencari probabilitas kesamaan kata dari dokumen buku yang akan diuji. Contoh dari TF dapat dilihat pada Gambar 6.

\subsubsection{Proses Klasifikasi}

Proses klasifikasi jenis buku mulai dilakukan setelah term yang dihasilkan dari data buku yang dijadikan sebagai dokumen training terbentuk. Pada bagian ini yang akan diuji adalah buku-buku yang dijadikan sebagai dokumen testing. Sebelum proses klasifikasi dilakukan, buku-buku testing harus melalui tahapan text preprocessing terlebih dahulu sampai pada tahap stemming. Dari tahap stemming ini dihasilkan kata-kata yang sudah tidak lagi memiliki imbuhan, awalan, akhiran dan kata depan 
untuk kemudian dicocokkan dengan kata kunci yang sudah diberikan dan dihitung probabilitasnya dengan algoritma klasifikasi. Tabel 6 di bawah ini memperlihatkan contoh simulasi hasil proses klasifikasi dokumen testing yang cocok dengan tabel kata kunci yang ada.

\begin{tabular}{|c|c|c|}
\hline $\begin{array}{l}\text { ACTIVE } \\
\text { SERVER } \\
\text { PAGES } \\
\text { DATABASE } \\
\text { dunia } \\
\text { database } \\
\text { mengubah } \\
\text { hidup } \\
\text { dimuka } \\
\text { bumi } \\
\text { datbase } \\
\text { diposisikan } \\
\text { alat } \\
\text { administratif } \\
\text {......... }\end{array}$ & Porter stemmer & $\begin{array}{l}\text { ACTIVE } \\
\text { SERVER } \\
\text { PAGES } \\
\text { DATABASE } \\
\text { dunia } \\
\text { database } \\
\text { ubah } \\
\text { hidup } \\
\text { muka } \\
\text { bumi } \\
\text { datbase } \\
\text { posisi } \\
\text { alat } \\
\text { administratif } \\
\text {......... }\end{array}$ \\
\hline
\end{tabular}

Gambar 5. Contoh Tahap Stemming

\begin{tabular}{|c|c|c|}
\hline $\begin{array}{l}\text { ACTIVE } \\
\text { SERVER } \\
\text { PAGES } \\
\text { DATABASE } \\
\text { dunia } \\
\text { database } \\
\text { ubah } \\
\text { hidup } \\
\text { muka } \\
\text { bumi }\end{array}$ & $\begin{array}{l}\text { Term } \\
\text { ACTIVE } \\
\text { SERVER } \\
\text { PAGES } \\
\text { DATABASE } \\
\text { Dunia } \\
\text { Hidup } \\
\text { Muka } \\
\text { Bumi }\end{array}$ & $\begin{array}{c}\text { Frekuensi } \\
1 \\
1 \\
1 \\
6 \\
1 \\
2 \\
1 \\
1\end{array}$ \\
\hline
\end{tabular}

Hasil TF

Hasil stemming

Gambar 6. Contoh Tahap Indexing

Tabel 6. Simulasi Hasil Proses Klasifikasi Dokumen Testing

\begin{tabular}{|c|c|c|c|}
\hline Judul Dokumen & Hasil & Kategori Akhir & Fitur (Kemunculan) \\
\hline $\begin{array}{l}\text { Membuat Database dengan Ms. } \\
\text { Access }\end{array}$ & Akurat. Sesuai dengan klasifikasi & Database & $\begin{array}{l}\text { Database(5), } \\
\text { Access(2),Aplikasi(1) }\end{array}$ \\
\hline $\begin{array}{l}\text { Tuntunan Praktis: Belajar } \\
\text { Database } \\
\text { Menggunakan MySql }\end{array}$ & Akurat. Sesuai dengan klasifikasi & Database & Database(3),DBMS(1) \\
\hline $\begin{array}{l}\text { Aplikasi Excel Untuk Guru Edisi } \\
\text { Revisi }\end{array}$ & Akurat. Sesuai dengan klasifikasi & Ms. Office & Excel(5),Aplikasi(1) \\
\hline Basis Data & Akurat. Sesuai dengan klasifikasi & Database & Basis(8),Data(7) \\
\hline Adobe in Design Creative Suite 2 & $\begin{array}{l}\text { Kurang akurat. } \\
\text { dengan klasifikasi }\end{array}$ & Ms. Office & Adobe(4),word(1) \\
\hline $\begin{array}{l}\text { Buku Pintar Pemrograman Delphi } \\
\text { untuk Pemula (Promo) }\end{array}$ & Akurat. Sesuai dengan klasifikasi & Delphi & Delphi(2),Program(1) \\
\hline $\begin{array}{l}\text { Dasar Pengolahan Citra dengan } \\
\text { Delphi }+\mathrm{CD}\end{array}$ & Akurat. Sesuai dengan klasifikasi & Delphi & $\operatorname{Delphi}(2), \operatorname{citra}(2)$, aplikasi(1) \\
\hline Asyiknya Mengenal JAVA & Akurat. Sesuai dengan klasifikasi & Java & Java(7),Program(4) \\
\hline Buku Sakti Webmaster (Promo) & Akurat. Sesuai dengan klasifikasi & $\begin{array}{l}\text { Pemrograman } \\
W e b\end{array}$ & Web(7),Database(3) \\
\hline Ide Bisnis Bermodal Blog & Akurat. Sesuai dengan klasifikasi & Internet & Blog(9),Aplikasi(2),Program(3) \\
\hline $\begin{array}{llll}\text { Belajar Desain } & \text { Grafis untuk } \\
\text { Pemula } & & & \\
\end{array}$ & Akurat. Sesuai dengan klasifikasi & Desain Grafis & CorelDraw(3),Photoshop(3) \\
\hline $\begin{array}{lll}\text { SPSS 22 } & \text { Pengolah } & \text { Data } \\
\text { Terpraktis } & & \\
\end{array}$ & Akurat. Sesuai dengan klasifikasi & SPSS & SPSS(4),Data(3) \\
\hline
\end{tabular}




\subsection{Implementasi}

Pada bagian ini dilakukan proses perancangan antar muka untuk mengimplementasikan seluruh tahapan text preprocessing. Perancangan antar muka ini menggunakan compiler Delphi 2010 seperti yang diperlihatkan pada Gambar 7, Gambar 8, dan Gambar 9.

\begin{tabular}{|c|c|c|c|c|}
\hline \multicolumn{3}{|c|}{ Data Dokumen Training } & \multirow{10}{*}{\multicolumn{2}{|c|}{\begin{tabular}{|l} 
Pemrograman database \\
Buku ini ditujukan untuk para programmer pemula yang ingin mengembangkan pengetahuan dan \\
kemahirannya di dalam membuat program database. Dengan penyajiannya yang menggunakan \\
bahasa yang mudah dimengerti dan tidak bertele-tele, dengan konsep yang jelas dan disertai \\
contoh penerapan program secara langsung, akan membantu para programmer untuk lebih \\
mengembangkan ilmunya. Buku ini dapat menjadi panduan untuk belajar database dengan cepat
\end{tabular}}} \\
\hline \multicolumn{3}{|c|}{ Kategori 4} & & \\
\hline \multirow{2}{*}{\multicolumn{3}{|c|}{$\begin{array}{l}\text { Judul } \\
\text { masukkan data yang dicari }\end{array}$}} & & \\
\hline & & & & \\
\hline \multicolumn{3}{|c|}{ Kategori : DATABASE } & & \\
\hline DOC01 & ACTIVE SERVER PAGES DATABASE & Tidak a & & \\
\hline $\mathrm{DOCO2}$ & Panduan lengkap menguasai perintah sql & Banyak & & \\
\hline DOC03 & Pemrograman database borland delphi dalamsql server 7.0 \& 2005 & Sekaran & & \\
\hline DOC04 & Pemrograman database & Buku ini & & \\
\hline DOC05 & Mysql untuk Pemula & Mengap & & \\
\hline DOC06 & Database Systems & Dalam d & \multirow{2}{*}{\multicolumn{2}{|c|}{ Drag a column header here to group by that column }} \\
\hline DOC07 & Sistem Basis Data Oracle $10 \mathrm{~g}$ & Oracle 1 & & \\
\hline DOC08 & Pemrograman Desktop Database Python-MYSQL Dengan BOA Contruc & Python a: & Kode Dokumen & Kata/Token \\
\hline DOC09 & Kolaborasi SQL Dan ERD Dalam Implementasi Database & Buku ini : & $00 C 04$ & Pemrograman \\
\hline DOC10 & ShortCourse Series: SQL Server 2012 & Shortco & DOC04 & database \\
\hline \multicolumn{3}{|c|}{ Kategori: MS. OFFICE } & DOC04 & Buku \\
\hline DOC11 & Buku Pintar Macro Microsoft Office Excel & Visual B & DOC04 & ini \\
\hline DOC12 & Secret Fungsi dan Formula pada Excel 2013 & Microsol| & DOC04 & ditujukan \\
\hline DOC13 & Optimalkan Bisnis Kita dengan Office 365 & Sering $\mathrm{k}$ & DOC04 & untuk \\
\hline DOC14 & Tips Microsoft Word untuk Perkantoran & Microsol & DOC04 & para \\
\hline DOC15 & Panduan VBA untuk Ms Office & Bagi per & DOC04 & programmer \\
\hline DOC16 & Kupas Tuntas Microsoft office 2010 Edisi Revisi & Buku ini & DOC04 & pemula \\
\hline DOC17 & Analisis Data dengan Excel & Excel $m$ & DOC04 & yang \\
\hline \multirow[t]{2}{*}{ DOC18 } & Membuat Dokumen Massal dengan Excel & Untuk m & DOC04 & ingin \\
\hline & \# & & DOC04 & mengembangkan \\
\hline \multicolumn{3}{|c|}{$\begin{array}{l}\text { Lakukan klik ganda pada daftar data dokumen training untuk melakukan parsing } \\
\text { Cell warna hijau menandakan bahwa dokumen sudah di parsing }\end{array}$} & Proses Parsing & Keluar \\
\hline
\end{tabular}

Gambar 7. Form Proses Tokenizing

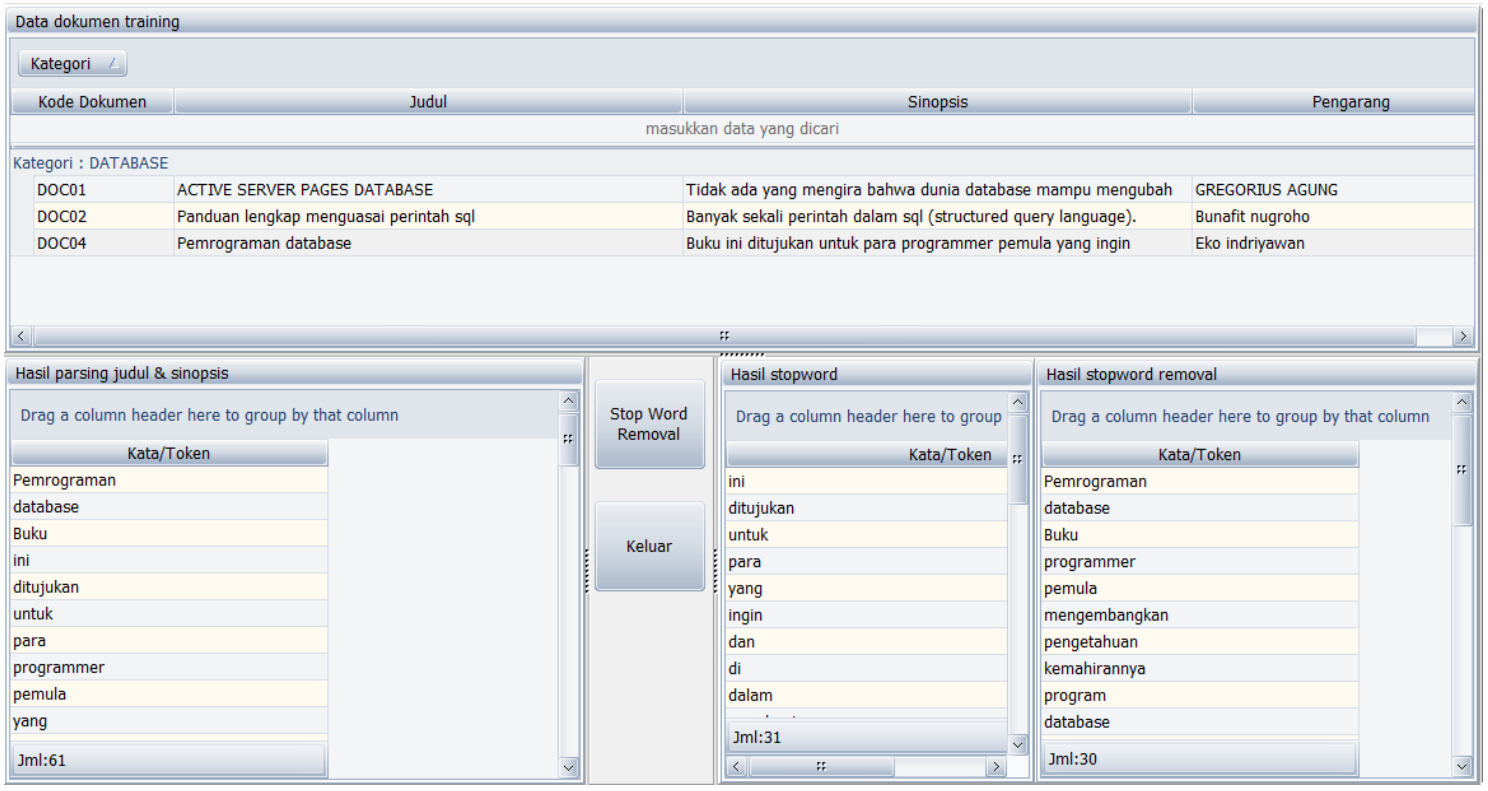

Gambar 8. Form Proses Stopword Removal 


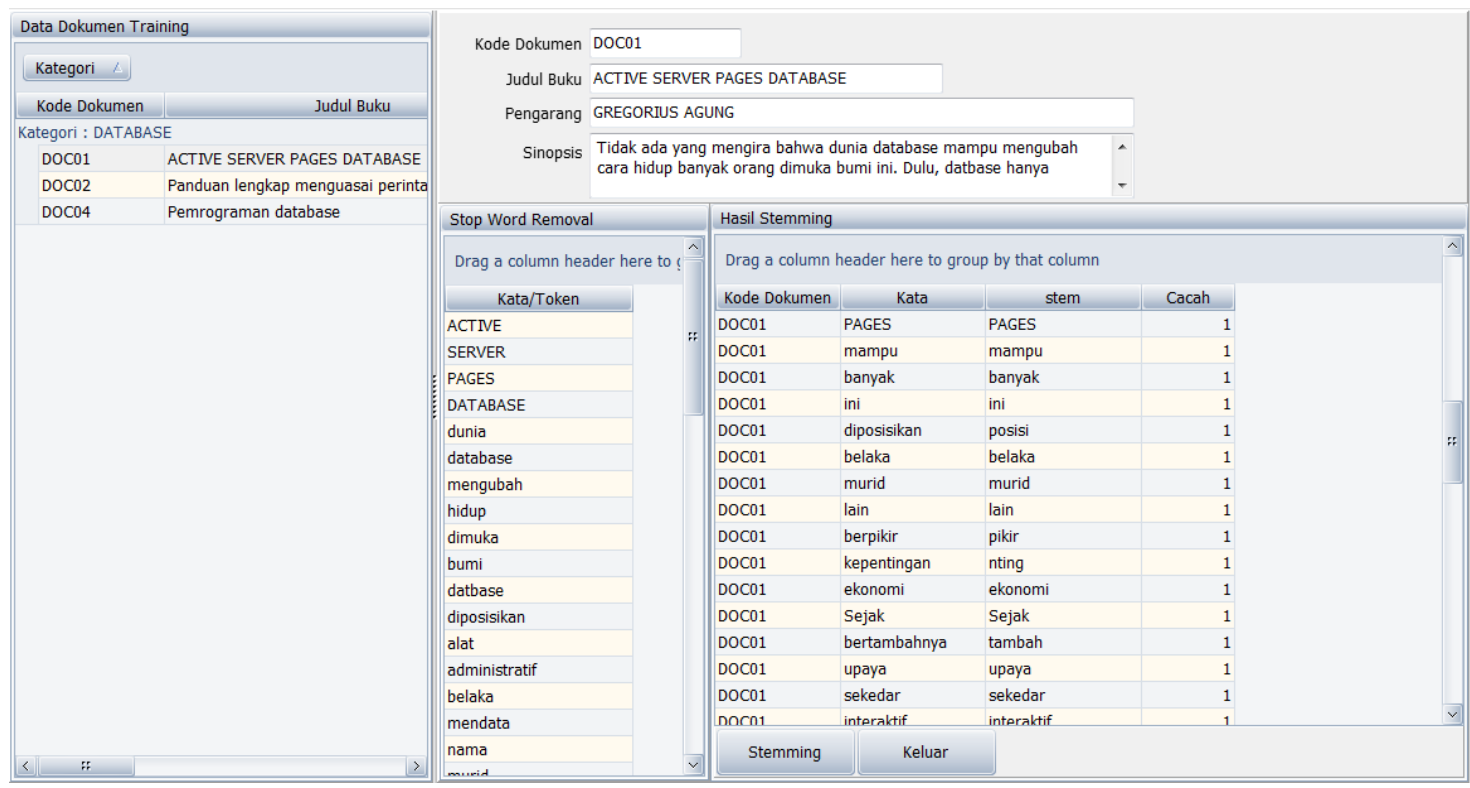

Gambar 9. Form Proses Stemming

\section{Kesimpulan dan Saran}

Berdasarkan hasil penelitian yang telah diuraikan pada bab sebelumnya dan perancangan prototype yang telah dilakukan, maka dapat diambil beberapa kesimpulan sebagai berikut: (1) Tahap text preprocessing yang dilakukan terhadap dokumen buku yang diuji semakin mempermudah untuk proses stemming. (2) Algoritma stemming dengan porter stemmer untuk Bahasa Indonesia yang menggunakan algoritma berbasis aturan sangat membantu mempercepat proses klasifikasi karena word yang dihasilkan dari dokumen-dokumen uji merupakan kata dasar yang semestinya sehingga memudahkan dalam pencocokan dengan kata kunci dan perhitungan probabilitas kemunculannya. (3) Prototype yang dibangun dengan penerapan aturan porter stemmer untuk Bahasa Indonesia ini dapat digunakan untuk membantu mempercepat dan mempermudah dalam proses klasifikasi jenis buku.

Penelitian ini menggunakan dokumen uji yang tidak terlalu banyak (900 buku) dan berdasarkan pada kriteria judul serta sinopsis buku, sehingga dapat diberikan saran bagi peneliti yang lain untuk menggunakan dokumen uji yang lebih banyak lagi dengan kriteria uji tidak hanya judul dan sinopsis agar hasil stemming dengan porter stemmer untuk Bahasa Indonesia lebih akurat.

\section{Referensi}

Agusta, L. 2009. Perbandingan Algoritma Stemming Porter Dengan Algoritma Nazief \& Adriani Untuk Stemming Dokumen Teks Bahasa Indonesia. Konferensi Nasional Sistem dan Informatika, Bali, 14 November.

Baskoro, D.O., Malik, H., \& Anshari, M.H. 2012. Porter Stemmer Information Retrieval. Mini Paper Project. Yogyakarta: Computer Science, Gadjah Mada University.

Budhi, G.S., Noertjahyana, A., \& Susilo, R.Y. 2012. Ekstraksi Kata Kunci Otomatis untuk Dokumen Berbahasa Indonesia menggunakan metode Genitor-plus-Extractor (GenEx). Seminar Nasional Teknologi Informasi dan Komputasi (SNASTIK), November, ISSN: 2302-7088.

Eryono, K. 1999. Penentuan Tajuk dan Bentuk Tajuk Nama Orang. Jakarta: Universitas Terbuka.

Frakes, W. B. \& Baeza, R. 1992. Information Retrieval Data Structure and Algorithms. New Jersey: Prentice-Hall.

Garcia, E. 2005. Document Indexing Tutorial, (Online), http://www.miislita.com/informationretrieval-tutorial/indexing.html, diakses pada tanggal 31 Oktober 2012. 
Han, J. \& Kamber, M. 2001. Data mining: Concepts and Techniques. San Francisco, CA, USA: Morgan Kaufmann Publishers Inc. ISBN: 1-55860-489-8.

Indranandita, A., Susanto, B., \& Rachmat, A. 2008. Sistem Klasifikasi Dan Pencarian Jurnal Dengan Menggunakan Metode Naive Bayes Dan Vector Space Model. Jurnal Informatika, Vol. 4 No. 2, November.

Karaa, W.B.A. 2013. A New Stemmer to Improve Information Retrieval. International Journal of Network Security \& Its Applications (IJNSA), Vol.5, No.4, July 2013.

Mulyanto, A. 2009. Sistem Informasi Konsep dan Aplikasi (Cetakan I). Yogyakarta: Pustaka Pelajar.

Porter, M. F. 1980. An Algorithm For Suffix Stripping. Program, 14(3), 130-137.

Pradnyana, G.A. \& Sanjaya, N.A. 2012. Perancangan Dan Implementasi Automated Document Integration Dengan Menggunakan Algoritma Complete Linkage Agglomerative Hierarchical Clustering. Jurnal Ilmu Komputer, 5(2).

Tala, F.Z. 2003. A Study of Stemming Efects on Information Retrieval in Bahasa Indonesia. Thesis. Institute for Logic Language and Computation Universiteit van Amsterdam TheNetherlands.

Tenenboim, L., Shapira, B., \& Shoval, P. 2008. Ontology-Based Classification of News in an Electronic News Paper. Paper presented at Intelligent Information and Engineering Systems Conference, Varna, Bulgaria.

Utomo, M.S. 2013. Implementasi Stemmer Tala pada Aplikasi Berbasis Web. Jurnal Teknologi Informasi DINAMIK Volume 18, No.1, Januari 2013, ISSN: 0854-9524.

Walpole, E. R. \& Myers, R. H. 1995. Ilmu Peluang dan Statistika untuk Insinyur dan Ilmuan (Edisi ke-4). Bandung: ITB. 